\title{
What constitutes success in brownfield redevelopment? A review
}

\author{
T. Silverthorne \\ Social Research Group, Forest Research, UK \\ Centre for Environmental Strategy, University of Surrey, UK
}

\begin{abstract}
This review identifies and examines the different definitions of success that appear in the literature on brownfield redevelopment and discusses perceptions of: greenspace creation; economic issues; sustainability and success models. It concludes with some insights into what is currently perceived to constitute success in brownfield redevelopment. Brownfield redevelopment is generally acknowledged as one of the principal factors in ensuring that development is sustainable, but there is neither a benchmark standard nor a list of criteria by which success can be defined. In many redevelopments that have been judged, primarily by the developers, to be successful there is little correlation between the criteria on which the success has been claimed and the social or economic wellbeing of the local residents and success may in fact occur at their expense. Success is usually measured against the original objectives of the project where the focus is often more towards economic factors rather than social and environmental factors. All of these variables make it very difficult to generically quantify success in brownfield redevelopment.
\end{abstract}

Keywords: evaluation, success, brownfield redevelopment, sustainable development, urban greening, green space creation.

\section{Introduction}

This literature review was carried out using internet searches and on-line databases such as Web of Knowledge. The review identifies and examines the different definitions of success for brownfield redevelopment that appear in the literature. The search focused on the published literature contained in journals, papers and reports of the past ten years predominately from Europe and North 
America. Search terms included: 'brownfield'; 'evaluation'; 'redevelopment'; 'success'; 'urban greening'.

In the UK, there have been many different definition of 'brownfield' reflecting the perspectives and practices of a wide range of users. The most commonly accepted definition of 'Brownfield' by planners and other stakeholders in the UK is 'any land or premises which has previously been used or developed and is not currently fully in use, although it may be partially occupied or utilised. It may also be vacant, derelict or contaminated. Therefore a brownfield site is not available for immediate use without intervention' Alker et al. [1, p. 64]. This crucially differs from the American definition because the site does not have to be contaminated to be classified as brownfield. Therefore, although contamination may not be present, a brownfield site is not necessarily available for immediate use without intervention. In Britain, The National Land Use Database (NLUD) states that there is currently 66,000 ha of brownfield land (EP [2]) and suggests that 6,500ha of previously developed land becomes classed as brownfield every year (ODPM [3]).

An evaluation of the success of brownfield redevelopment projects requires a benchmark of success against which the success of individual projects can be measured. However, there is no overarching definition of success contained in the literature and the majority of evaluations are on a very site specific basis. Therefore, in view of the increasing emphasis on the need for brownfield redevelopment and the large sums of money now being invested in these projects, it is very important that there should be a broader definition of success. This review highlights the need for such a definition and suggests factors that should be included in such a definition.

England is the most densely populated country in Europe and is the fourth most densely populated country on the Earth (EP [2]) with four out of five inhabitants living in urban areas (DETR [4]). By 2016 it is estimated that 1.1 million new houses will be required in the south-east (ODPM [5]) to accommodate an expanding population, changes in patterns of household occupancy such as increasing rates of single parent and single person households and the effects of increased life expectancy.

In order to meet government targets for the building of infrastructure and new homes, Carey [6] concludes that brownfield sites will need to be rapidly brought into use. According to the Council for the Protection of Rural England (CPRE), there is now a greater need than ever for brownfield redevelopment due to the increasing threat to the greenbelt by current Government policies. In 2005 there were approximately 160,000 new homes built in the south-east (CPRE [7]), the Sustainable Communities Plan aims for 200,000 new homes in the south-east every year by 2016 and, according to the CPRE, a series of greenbelt boundary reviews are planned (GP [8]).

Brownfield redevelopment is generally acknowledged as one of the principal factors in ensuring that development is sustainable (Grimski and Ferber [9]). According to the OECD [10], brownfield redevelopment is 'part of a larger effort to address land use problems throughout urban regions, the better to control urban sprawl, improve social cohesion and create conditions favourable 
to local economic development' (Moore [11, p. 326]). The problem is that brownfield redevelopment is often viewed as having either no, or even a negative, economic value [12-14]. In the past, in the face of increasingly powerful economic pressures, there has been a tendency to define the success of brownfield redevelopment schemes in economic terms to justify the expense and effort involved. Therefore it is now of vital importance when formulating a definition of success of redevelopment projects to include factors relating to the success of the social objectives with regard to the original stakeholders and the local communities.

\section{Definitions of success}

The main problem with defining success is that while appearing simple, it is in fact a concept that has numerous dimensions and there is not one comprehensive model or formula within existing frameworks (Layne [15]).

A definition of what constitutes success contained in a report for the Department of the Environment, Transport and the Regions (DETR) is 'if an area no longer experienced economic, social housing and environmental problems except those displayed on average throughout England' (DLEUC [16, p. 59]). This implies that for the government success is just an absence of failure.

The way success is generally judged is on a site specific basis and simply involves an appraisal of whether or not the original objectives of the stakeholders have been achieved. For example, at the Fairfield Ecological Industrial Park in Baltimore (USA) more than 13,000 acres were zoned for industrial development. The notion of what constitutes success from this site is derived purely from the original intention for industrial ecology and does not include a wider concept for a standard of success (SGN [17]).

Success can also be measured by: environmental remediation; civil infrastructure renewal; job creation; tax-based development; economic development and neighbourhood revitalisation (Amekudzi and Fomunung [18, p. 211]). Although, it is worth noting that the measurement of these indicators can be very difficult and time consuming and the results are often disputed because the methodologies used to collect the data are often inappropriate. Also, the wide range of variables that can influence these factors make it difficult to prove a clear cause and effect relationship.

A more simplistic approach to measuring success is the view that any redevelopment of a brownfield site must be an improvement and therefore a success due to the inherent problems and costs associated with unimproved brownfield sites. These costs can be classified as economic, social and environmental (Burnham-Howard [19]). An unimproved brownfield site can attract a great deal of anti-social and criminal behaviour including arson, flytipping and vandalism.

Brownfield redevelopment has often been seen as a success in terms of both improving environmental quality and reducing the demand for greenfield development. Indeed, the US Council of Environmental Quality stated that 
'every acre of reclaimed brownfields saves 4.5 acres of greenspace' from being redeveloped (WHCEQ [20]).

\section{Green space creation}

One definition of success by planners, applied geographers and economic development practitioners is to 'create liveable spaces that enrich the daily lives of residents' (Gatrell and Jensen [12, p. 331]). Within the US, there has been a move towards alternative economic development with 'smart growth' economic plans. These try to balance the often competing interests of the economy, the environment and quality of life by focusing on the overall liveability of the locality and the importance of a sense of place (English [21]). Within this school of thought, urban forestry is seen as encapsulating successful brownfield redevelopment due to its contribution to the quality of life in the locality. Urban forestry can be coupled with economic development and a community's smart growth strategy as studies from Florida have shown.

Within the UK, there has been a growing trend for greening, more so than in the US. For instance, between 1988 and 1993, over 19\% of brownfield redevelopments were converted into green spaces, which was more than any other end use (DETR [22]), whereas in the US, the emphasis has been on economic benefits (De Sousa [23]). However, this is not to say that economics are not a consideration in the UK. The North West Development Agency views the greening of the north-west of England as bringing economic benefits through investment in an attractive area and subsequent relocation of business.

When it comes to redevelopment in the form of urban greening, involving 'all public and private urban spaces that are not built or otherwise fully impervious' (Jensen et al. [24, p. 118]), there is a growing definition of success in the literature that states that green redevelopment should involve a multi-functional view of development that encompasses economic, environmental, recreational and aesthetic issues and involve communities in the decision making process.

Urban green space is becoming an increasingly popular option for brownfield redevelopment with 33 million inhabitants making an estimated 2.5 billion trips each year to these areas in the UK (Dunnett et al. [25]). Money is now being made available for urban green space development on brownfield land by the Heritage Lottery Urban Parks Fund (ODPM [26]). These areas can be judged to be a success by looking at their utilisation for social activities. Dunnett et al. [25] listed the following activities: sporting activities; quiet time; walking; attending events; social activities and passive activities such as reading or sitting.

From a social point of view, one of the criteria for success is its aesthetic appeal and characteristics. Although there are some attempts in the published literature to assess the beauty of forests and green areas [27, 28], this is notoriously difficult to assess and quantify.

Studies have shown that the success of brownfield redevelopment is not solely due to environmental factors and that success cannot be achieved by just addressing the environmental issues. This was the conclusion of a study that was carried out in the US by Lang and McNeil [29]. The study concluded that the 
differences between successful and non-successful redevelopment sites were not based on site specific criteria such as size; distance to an airport or city centre; rail access or frontage onto water but were dependant on: time to occupancy; land use; preservation / creation of greenspace; relative cost of remediation; availability of incentives; integration of the property into the neighbourhood and the willingness of the banks and political forces to find co-operative solutions (Lang and McNeil [29, p. 107]).

The study also concluded that due to the importance of land-use and time to occupancy, when assessing the success of a redevelopment project, there is a need to focus on the two primary stakeholder groups: the community, who need to be assured that the development is in tune with the social and economic needs of the community; and the developer / investor who looks for a return on their investment (Lang and McNeil [29]).

From an economic perspective, it is more difficult to assess the success of a brownfield greening project such as urban forestry because urban green areas do not usually generate income and are generally perceived as public services without any economic value $[12,13]$. However, there are likely to be strong benefits to the surrounding area in the form of higher property values. Protagonists argue that environmental improvements such as the presence of trees and forested areas create better living spaces which will also have the effect of improving the quality of economic development and an increased property value $[30,31]$. This trend can also be seen in the UK. Thames Barrier Park in London is a free public amenity and so does not make much money, but it led to executive flats being built in the immediate surrounding area (Holden [32]). Tyrvainen and Miettinen [33] observed that there is also a statistically significant correlation between closeness to green space and the value of property with a $5.9 \%$ decrease in market price with every $\mathrm{km}$ away from a wooded area. There is also a rise in the quality of life indicators (Gatrell and Jensen [12]). This form of redevelopment ultimately enhances the local system (Anderson and Cordell [30]), thus making for a successful redevelopment.

\section{Economic issues}

One of the main disincentives for developers facing brownfield redevelopment is that the focus is all too often on economic benefit; however, the benefits to the stakeholders are frequently intangible, with the implication that any other benefits are secondary and a possible positive side-effect. This point of view is expressed by Burnham-Howard [19, p. 213] who stated 'Each brownfield site represents untapped potential for economic development in the form of community benefits in jobs and tax revenue'. Brownfield greening can help the local economy because it is now generally accepted that 'what tends to attract higher economic functions, besides the quality of the labour force, is the quality of the environment' (Zetter [34 p. 57]).

Because brownfields are historically and predominately viewed in economic terms (although this is beginning to change, albeit slowly) success is often judged within this narrow category. Howland [35, p. 2] concluded that two 
brownfield redevelopment sites in Baltimore (US) were a success because they have 'profitable enterprises now operating on both' with just three years between the purchase of land to a profitable operation. This economic focus is due to the fact that in the US, brownfields are viewed in the main as 'a currently unrealised asset' (Lang and McNeil [36]) or as 'under utilised' (De Sousa [23, p. 181]). Similarly, in the UK the prevailing view is of brownfield land as 'wasting assets' (UTF [37]) and this has given rise to the dominant view that redevelopment is a way to bring this land into beneficial use. Therefore any redevelopment can be classed as a success because any alternative is better than a derelict brownfield site with its association with socially undesirable activities.

If success is only measured from an economic perspective, it is relatively easy to achieve a successful outcome. There have been numerous success stories from the US over the last 10 years with idle and under-utilised contaminated properties now housing a variety of economic activities, both single and mixed use, such as leisure complexes, urban villages, commercial estates and industrial estates. It is, however, unclear whether these developments have helped to revitalise the surrounding area by contributing to a more sustainable community. One of the reasons for this is that the usual gross metrics such as job creation, often fail to distinguish between jobs transferred from other industries and new job creation, nor do they take into account the more social aspects of the community such as quality of life, social cohesion and environmental justice.

\section{Sustainability}

The redevelopment of brownfield land can be viewed as successful if it yields substantial results in the three pillars of sustainable development: environmental, social and economic (Andrew [38]) and so the success of redevelopment has the potential to solve multiple problems through a single activity (Strother [39]).

A major difficulty with judging the sustainability success of brownfield redevelopment based on sustainable development, especially the social aspect, is the problem of measurability. Some of the aspects of sustainability, especially the social aspects are difficult to quantify, such as the aesthetic values, community interaction and feelings of safety. An additional problem is the fact that environmental and economic objectives are often judged to be incompatible with each other.

Mixed-use developments have been seen as successful because of their potential to combine the elements of sustainable development. It can be a stand alone development such as an urban village, e.g. the Hulme area in Manchester (EP [40]), or where smaller mixed use projects are part of a larger regeneration drive. One successful example can be found in Norrkopping, Sweden (CLARINET [41]), another at the Salts Mill in Bradford, where a former textile mill is now a mixed use development incorporating an IT research facility, retail, cultural and commercial outlets with over 750 people employed on the site (Alker and McDonald [42]). According to Alker and McDonald [42], the success of this type of project is a result of the integration of the community and the other stakeholders who all assessed aspects of the proposed redevelopment. 
In the current political climate, due in part to the growing trend of ecological modernisation (Buttel [43]), developers are adopting a greener approach and so newer developments are offering advantages and opportunities for wildlife where ten years ago, none would have been forthcoming. Thus offering another opportunity for redevelopment to be considered a success.

\section{Success models}

There is a lack of tools for dealing with the assessment of brownfield redevelopment. The majority of the literature deals with anecdotal and qualitative studies and there are very few systematic studies that show what is successful and what is not and, more importantly, how to define a successful brownfield redevelopment. Nijkamp et al. [14] have developed a model from Dutch case studies that uses a meta-analytic approach for determining success when redeveloping contaminated brownfield sites. However, this looks more at the success of the process of redevelopment rather than the final outcome including problems with financing, jurisdictional responsibility and regulatory compliance.

More recently, Lang and McNeil [29] have developed a logit model which utilises data from 75 brownfield sites in the US and analyse the data to distinguish between the successful and the unsuccessful. They state that this can be used to estimate the probability of success. When making the model, they concluded that successful sites: incorporated more greenspace into the development plan; were more likely to take advantage of existing infrastructure; were more likely to have financial incentives available to the developer; were better integrated into the neighbourhood and will have a positive effect on local businesses and considered the future use of the property when establishing environmental cleanup levels (Lang and McNeil [29, p. 110]).

\section{What constitutes success?}

There are many different definitions concerning the success of brownfield redevelopment. There does not seem to be one bench mark standard. Bodies such as the US Environment Protection Agency (EPA) and the Office of the Deputy Prime Minister (ODPM) do not have a list of criteria for which success can be defined. Instead, success is measured against the original intentions of the redevelopment, which is broad ranging and on a site specific basis. The majority of the focus though has been on the economic success of a site with relatively little done to assess the social success of the site. This is because traditionally, the reason for regeneration is an economic one.

There is also variation due to the different types of redevelopment and the ultimate end-use of the sites. Different countries have different ideas as to what type of greenspace is wanted (Grimski and Ferber [9]). All of these variables make it very difficult to generically quantify success for brownfield redevelopment. 
Perhaps one of the most important questions, and the most overlooked, when addressing the success of redevelopment projects is the question 'success for whom?' There have been a number of authors who have observed that the successful redevelopment does not always correlate with the social or economic wellbeing of the local residents, and may in fact occur at their expense [15, 44].

Environmental improvement is not usually perceived as a criterion for success. In a study conducted by Wernstedt et al. [45, p. 10], more than $80 \%$ of the respondents of a public sector survey thought that a more efficient use of public infrastructure, the increase in tax revenue, neighbourhood revitalisation and the creation of jobs were the main reasons for brownfield redevelopment and it is on this basis that they would be judged a success. The attention and priority appears to be on social and economic success factors rather than environmental.

There is a growing debate in the literature that states that the involvement of all stakeholders (people in the community, the developer, local government and regulators) from the beginning is essential for successful brownfield regeneration and the sites integration into the surrounding community (Stenner et al. [46]). Villavaso et al. [47] argue that local communities need the tools to 'assess, cleanup and reuse contaminated [brownfield] properties' with an integration between the local community and the possible developers and they go on to suggest how this can be achieved for successful redevelopment.

There is now wider recognition that successful brownfield redevelopment should encompass sustainable development with ecological sustainability; social equity; and economic efficiency with clearly defined long-term objectives so that the expectations of stakeholders remain constant (Agrawal [48]). However, Pagdee et al. [49] argues that a proportionate combination of these three pillars may not exist owing to nearly all of the casual elements being subject to change. It is clear that there is no one definition of success as it depends on what the objectives and aims of the site were, one's personal perspective and interests and on definitions of success which may vary amongst the stakeholders of the same redevelopment project. There is, however, a clear theme emerging that any definition of success must ensure that there is meaningful consultation by the developers with the local community; potential stakeholders including user groups; the project is sustainable for the long-term; improves the local environment and addresses the needs of the local community.

\section{Acknowledgements}

The author is registered on an Engineering Doctorate Programme at the University of Surrey and gratefully acknowledges the support of the EPSRC and Forest Research. The author would also like to thank Dr. Liz O'Brien at Forest Research and Dr. Walter Wehrmeyer, Dr. Kate Burningham at the University of Surrey. 


\section{References}

[1] Alker, S., Joy, V., Roberts, P. \& Smith, N., The definition of brownfield, Journal of Environmental Planning and Management, 43(1), pp. 49-69, 2000.

[2] EP [English Partnerships], Towards a national brownfield strategy, English Partnerships: London, 2003.

[3] ODPM [Office of the Deputy Prime Minister], Landfill tax and the development of brownfield land. http://www.odpm.gov.uk/stellent /groups/odpm urbanpolicy/documents/pdf/odpm urbpol pdf 608149.pdf

[4] DETR [Department of the Environment, Transport \& the Regions], Contaminated land: Implication of part IIA of the Environmental Protection Act 1990, HMSO: London, 2000.

[5] ODPM [Office of the Deputy Prime Minister], Delivering growth in the Thames Gateway and the growth areas. www.odpm.gov.uk/stellent /groups/odpm_communities/documents/page/odpm_comm_023301.hcsp

[6] Carey, A., Briefing: Bringing brownfield sites back into use, Municipal Engineer, 157 (ME4), 231-237, 2004.

[7] CPRE [Council for the Protection of Rural England], Housing supply. http://www.cpre.org.uk/campaigns/planning/housing-supply/index.htm

[8] GP [Green Places], CPRE warns of loss of green belt, Green Places, 16(6), 2005.

[9] Grimski, D. \& Ferber, U., Urban brownfields in Europe, Land contamination and reclamation, 9(1), 143-148, 2001.

[10] OECD [Organisation for Economic Co-operation and Development], Urban brownfields, OECD: Paris, 2000.

[11] Moore, N. M., From indigenous industry to foreign finance: The changing face of Dublin Docklands, Land Use Policy, 19, 325-331, 2002.

[12] Gatrell, J. D. \& Jenson, R. R., Growth through greening: Developing and assessing alternative economic development programmes, Applied geography, 22, 331-350, 2002.

[13] Harrison, C. \& Davis, G., Conserving biodiversity that matters: Practitioners perspectives on brownfield development and urban nature conservation in London, Journal of environmental management, 65, 95-108, 2002.

[14] Nijkamp, P., Rodenburg, C. A. \& Wagentonk, A. J., Success factors for sustainable urban brownfield development: A comparative approach to polluted sites, Ecological economics, 40, 235-252, 2002.

[15] Layne, J., Marked for success??? The Winnipeg Core Area Initiative's approach to urban regeneration, Canadian Journal of Regional Science, Summer, 249-278, 2000.

[16] DLEUC [Department of Land Economy in the University of Cambridge], Evaluation of the single regeneration budget challenge fund: An examination of baseline issues, A report for the DETR, DLE: Cambridge, 1999. 
[17] SGN [Smart Growth Newtork], Fairfield ecological park, Baltimore, Maryland. www.smartgrowth.org/casestudies/ecoin fairfield.html

[18] Amekudzi, A. \& Fomunung, I., Integrating brownfields redevelopment with transportation planning, Journal of Urban Planning and Development, 130(4), 204-212, 2004.

[19] Burnham-Howard, C. E., Building on brownfields: Predicted effects of new liability protections for prospective purchasers and an exploration of other redevelopment incentives, Journal of Professional issues in engineering education and practice, 130(3), 212-225, 2004.

[20] WHCEQ [White House Council on Environmental Quality], Over 1,000 to be trained for environmental jobs in brownfields communities nationwide, CEQ E-Notes, 2(13), 2004.

[21] English, M., A guide for smart growth. Forum for applied research and public policy, 14(3), 35-39, 1999.

[22] DETR [Department of the Environment, Transport \& the Regions], Derelict land surveys in 1988 and 1993, HMSO: London, 1998.

[23] De Sousa, C. A. Turning brownfields into green space in the city of Toronto, Landscape and urban planning, 62, 181-198, 2003.

[24] Jensen, M. B., Persson, B., Guldager, S., Reeh, U. \& Nilsson, K., Green structure and sustainability: Developing a tool for local planning. Landscape and urban planning, 52, 117-133, 2000.

[25] Dunnett, N., Swanwich, C. \& Woolley, H., Improving urban parks, play areas and green spaces, HMSO: London, 2002.

[26] ODPM [Office of the Deputy Prime Minister], Creating sustainable communities: Greening the gateway, HMSO: London, 2004.

[27] Brunsen, M. W. \& Shelby, B., Assessing recreational and scenic quality. How does new forestry rate? Journal of Forestry, 90, 37-41, 1992.

[28] Akbar, K. F., Hale, W. H. G. \& Headley, A. D., Assessment of scenic beauty of the roadside vegetation in northern England, Landscape and Urban Planning, 63, 139-144, 2003.

[29] Lang, D. A. \& McNeil, S., Clean it up and will they come? Defining successful brownfield development, Journal of urban planning and development, 130(2), 101-108, 2004.

[30] Anderson, L. \& Cordell, H., Residential property values improving with trees. Scandinavian Journal of Applied Forestry, 9, 162-166, 1985.

[31] Morancho, A. B., A hedonistic valuation of urban green areas, Landscape and urban planning, 66, 35-41, 2003.

[32] Holden, R., Park and pride: Creating an urban park., The architects journal, July, 2001.

[33] Tyrvainen, L. \& Miettinen, A., Property pries and urban forest amenities, Journal of environmental economic and management, 39, 205-223, 2000.

[34] Zetter, J., Frameworks for sound urban policy implementation, Town \& Country Planning, 74 (2), 57-60, 2005.

[35] Howland, M. What makes for a successful brownfield redevelopment? Three Baltimore case studies. www.smartgrowth.umd.edu/ research/pdf/HowlandBrowns. 
[36] Lang, D. A. \& McNeil, S., Brownfield development: Tools for stewardship, Journal of urban planning and development, 130(2), 109-116, 2004.

[37] UTF [Urban Task Force], Towards an urban renaissance, E. \& F. N. Spoon: London, 1999.

[38] Andrew, A. S., Brownfield redevelopment: A State led reform of superfund liability. Natural Resources and Environment, 10(3), 27-31, 1996.

[39] Strother, P. C., Brownfields of dreams in the old dominion: Redeveloping brownfields in Virginia, William and Mary Environmental Law and Policy Review, 23, 269-304, 2000.

[40] EP [English Partnerships], Mixing places: A guide to good practice in undertaking mixed development schemes, Urban villages forum, English Partnerships: London, 1999.

[41] CLARINET [Contaminated Land Rehabilitation Network for Environmental Technologies], The report of the CLARINET working group on brownfield redevelopment 1998 - 2001. www.clarinet.at

[42] Alker, S. \& McDonald, A., Incorporating sustainable development into redevelopment, Sustainable Development, 11, 171-182, 2003.

[43] Buttel, F., Ecological modernisation as a social theory, Gerforum, 31, 57-65, 2000.

[44] Wolman, H. L., Ford III, C. C. \& Hill, E., Evaluating the success of urban success stories, Urban Studies, 31, 835-850, 1994.

[45] Wernstedt, K., Heberle, L., Alberini, A. \& Meyer, P., The brownfields phenomenon: Much ado about something or the taming of the shrewd? Discussion paper 04-46. www.rff.org

[46] Stenner, R. D., Hull, R. N. \& Willes, R. F. Involving stakeholders to achieve successful development of brownfield sites. Brownfield sites: Assessment, rehabilitation and development eds. C. A. Brebbia, D. Almorza, \& H. Klapperich, WIT Press: Southampton, 2002.

[47] Villavaso, S., Sinel, P. \& Dauterive, L. The brownfields cookbook: A redevelopment guide. Brownfield sites: Assessment, rehabilitation and development eds. C. A. Brebbia, D. Almorza, \& H. Klapperich, WIT Press: Southampton, 2002.

[48] Agrawal, A., Common property institutions and sustainable governance of resources, World Development, 29(10), 1649-1672, 2001.

[49] Pagdee, A., Kim, Y. \& Daugherty, P. J., What makes community forest management successful: A meta-study from community forests throughout the world, Society and Natural Resources, 19(1), 33-52, 2006. 